\title{
The role of nucleotides and purinergic signaling in apoptotic cell clearance - implications for chronic inflammatory diseases
}

\author{
Jin Chen, Yi Zhao* and Yi Liu \\ Department of Rheumatology and Immunology, West China Hospital, Sichuan University, Chengdu, Sichuan, China
}

\section{Edited by:}

Martin Herrmann,

Universitätsklinikum Erlangen,

Germany

Reviewed by:

Pablo Pelegrin, Fundacion Formacion

Investigacion Sanitaria Region Murcia,

Spain

Luis Enrique Munoz,

Friedrich-Alexander University,

Germany

*Correspondence:

Yi Zhao, Department of

Rheumatology and Immunology,

West China Hospital, Sichuan

University, 37\# Guoxue Xiang,

Chengdu, Sichuan 610041, China

e-mail: zhao.y1977@163.com

\begin{abstract}
Billions of cells undergo apoptosis every day in healthy individuals. A prompt removal of dying cells prevents the release of pro-inflammatory intracellular content and progress to secondary necrosis. Thus, inappropriate clearance of apoptotic cells provokes autoimmunity and has been associated with many chronic inflammatory diseases. Recent studies have suggested that extracellular adenosine $5^{\prime}$-triphosphate and related nucleotides play an important role in the apoptotic clearance process. Here, we review the current understanding of nucleotides and purinergic receptors in apoptotic cell clearance and the potential therapeutic targets of purinergic receptor subtypes in inflammatory conditions.
\end{abstract}

Keywords: ATP, extracellular nucleotides, purinergic signaling, apoptotic cell clearance, chronic inflammation

\section{INTRODUCTION}

Apoptosis occurs in all multicellular organisms and plays a role in getting rid of superfluous and senescent cells during the development of an organism, tissue homeostasis, and pathogenic processes (1). In contrast to necrosis, apoptosis is a highly organized and fine-tuned process, and is, therefore, usually referred to as programed cell death. Besides the physiological process, apoptotic cells are also observed in tumors (2), atherosclerotic plaques (3, 4 ), and autoimmune diseases $(5,6)$. Under normal conditions, the apoptotic cell removal is performed very efficiently and fast by neighboring or recruited phagocytes and is important for maintaining the function of tissues $(6,7)$. Dying cells can undergo secondary necrosis if not cleared promptly and the release of intracellular contents has been linked to many human inflammatory diseases $(8,9)$. Moreover, apoptotic cells have been shown to have anti-inflammatory and regenerative effects (10).

Damaged tissues and dying cells can release nucleotides, which are increasingly viewed as a new class of regulators of the immune system. The class of purinergic receptors is involved in a wide range of phagocytic and chemotactic processes (11). Moreover, the purinergic signaling is an important regulatory mechanism in several inflammatory diseases (12). Several studies provide strong evidence that nucleotides and activated purinergic receptors are linked to the pathogenesis of many chronic inflammatory diseases. This review will discuss the apoptotic cell clearance with special emphasis the specific role of nucleotides and the purinergic receptors in the development of chronic inflammatory diseases related with abnormal clearance of apoptotic cells.

\section{COMPONENTS OF PURINERGIC SIGNALING}

\section{EXTRACELLULAR ATP RELEASE AND METABOLISM}

Damaged tissues and dying cells can release adenosine 5'triphosphate (ATP) as a danger signal that triggers a variety of inflammatory responses. Moreover, ATP can also actively be released from intact cells in response to mechanical deformation, hypoxia or acetylcholine, which do not damage the cell $(7,13,14)$. For example, ATP release from intact cells was firstly reported for neuronal cells, which release ATP into the cleft of chemical synapses (15). However, the underlying mechanism has been shown to be very complex and includes stretch-activated channels, voltage-dependent anion channels, $\mathrm{P} 2 \mathrm{X} 7$ receptors, and connexin and pannexin hemichannels (16).

Contrasting to intracellular ATP, primarily utilized as energy, extracellular ATP is considered to be a powerful signaling molecule through the nucleotide-selective P2 receptors. Extracellular ATP is rapidly metabolized to adenosine by ectonucleotidases (17). The ectonucleotidases consist of four family types including (i) ectonucleotide pyrophosphatase/phosphodiesterase (E-NPP) family, (ii) ectonucleoside triphosphate diphosphohydrolase (E-NTPDase) family, (iii) alkaline phosphatases (AP), and (iv) ecto-5'-nucleotidase (also known as CD73) $(17,18)$. Extracellular adenosine, an intermediate metabolite of nucleotides, can undergo three processes: (i) conversion to inosine by adenosine deaminase, (ii) reconversion to AMP by adenosine kinase, and (iii) cellular reuptake through concentrative nucleoside transporters (CNTs) or equilibrative nucleoside transporters (ENTs) $(17,19,20)$. 


\section{PURINERGIC RECEPTORS}

Purinergic receptors have been widely studied in signaling systems in response to extracellular ATP and related nucleotides. Purinergic receptors consist of three major families based on their structural and biological properties (21). The G-proteincoupled P2Y receptors (P2YRs) recognize ATP and several other nucleotides, including ADP, UTP, UDP, and UDP-glucose (22). P2X receptors (P2XRs) function as ATP-gated ion channels that facilitate the influx and efflux of extracellular cations, including calcium ions, which only respond to $\operatorname{ATP}(22,23)$. To date, P2YRs consist of eight subtypes, a family of P2Y1, P2Y2, P2Y4, P2Y6, P2Y11, P2Y12, P2Y13, and P2Y14Rs. P2XRs have seven subunits that may form six homomeric (P2X1-P2X5Rs and P2X7R), and at least seven heteromeric $\mathrm{P} 2 \mathrm{X} 1 / 2, \mathrm{P} 2 \mathrm{X} 1 / 4, \mathrm{P} 2 \mathrm{X} 1 / 5, \mathrm{P} 2 \mathrm{X} 2 / 3$, $\mathrm{P} 2 \mathrm{X} 2 / 5$, P2X2/6, and P2X4/6Rs receptors (23-25). The conversion of ATP/ADP to adenosine by ectonucleotidases terminates P2R signaling within the extracellular compartment. Adenosine can signal through four distinct G-protein-coupled receptors (P1 receptors): adenosine $\mathrm{A} 1$ receptor $(\mathrm{A} 1)$, adenosine $\mathrm{A} 2 \mathrm{a}$ receptor $(\mathrm{A} 2 \mathrm{a})$, adenosine $\mathrm{A} 2 \mathrm{~b}$ receptor $(\mathrm{A} 2 \mathrm{~b})$, and adenosine $\mathrm{A} 3$ receptor (A3) (Table 1) (26-28). The purinergic receptor subtypes are widely distributed throughout the immune cells and the central nervous system (CNS) (Table 1) (29-31).

\section{APOPTOTIC CELL RECOGNITION AND CLEARANCE}

Apoptosis is a crucial process during development and regeneration of an organism. The prompt and efficient engulfment of apoptotic cells by phagocytes is necessary to prevent inflammation resulting from uncontrolled release of intracellular contents (34). Apoptotic cell clearance can be subdivided into four general steps: sensing of the apoptotic cell, recognition, engulfment of the corpse, and processing of the engulfed material $(7,35-38)$. Many key molecules and several molecular pathways have been identified to orchestrate the safe disposal of apoptotic cells. Apoptotic cells release so-called "find me" signals, which are cell-derived chemoattractants to entice phagocytes (9). To date, several proposed "find me" signals released by dying cells have been reported. These include the nucleotides ATP and UTP (39), lysophosphatidylcholine (LPC) (40), fractalkine (CX3CL1) (41), and sphingosine 1phosphate (S1P) (42). In addition to attracting phagocytes, apoptotic cells are thought to release factors, referred to as "stay away" signals, to exclude inflammatory cells such as neutrophils (43).

At the same time, apoptotic cells also expose phosphatidylserine (PS) on the outer leaflet of the plasma membrane as an "eat-me" signal to promote their recognition by the recruited phagocytes $(44,45)$. PS can be detected directly through membrane receptors, such as brain-specific angiogenesis inhibitor 1 (BAI1) (46),

Table 1 | Characteristics of purinergic receptors [Modified from Ref. $(15,29,32,33)$ ]

\begin{tabular}{ll}
\hline Receptor & Distribution \\
\hline P2Y P2Y1 & $\begin{array}{l}\text { Platelets, immune cells, epithelial and endothelial } \\
\text { cells, and osteoclasts }\end{array}$ \\
P2Y2 & $\begin{array}{l}\text { Astrocytes, immune cells, epithelial and endothelial } \\
\text { cells, and osteoblasts }\end{array}$
\end{tabular}

P2Y4 Endothelial and epithelial cells

P2Y6 Activated microglia, T cells, and epithelial cells

P2Y11 Dendritic cells, granulocytes

P2Y12 Platelets and glial cells

P2Y13 Spinal cord microglia, hepatocytes

P2Y14 Hematopoietic cells, immune cells

P2X P2X1 Platelets, smooth muscle

P2X2 Autonomic and sensory ganglia, retina

P2X3 Sensory neurons, sympathetic neurons

P2X4 Microglial cell, immune cells

P2X5 Dendritic cells

P2X6 Neuron, retina, and myocardial cell

P2X7 Immune cells, osteoclasts, and microglia

P1 A1 Neurons, autonomic nerve terminals

A2a B cells, $T$ cells

A2b Bronchial epithelial cells, cardiomyocytes

A3 Endothelial cells, immune cells, and cardiomyocytes

\section{Functions}

Platelet aggregation, smooth muscle relaxation, and bone resorption

Promotes apoptotic cell removal; mediates airway surfactant secretion and epithelial cell chloride secretion; vasodilatation through endothelium and vasoconstriction through smooth muscle; bone remodeling; role in neutrophil chemotaxis; and chronic inflammation

Epithelial chloride transport regulation; vasodilatation through endothelium

Enhances microglial phagocytic capacity; modulating cytokines release; epithelium $\mathrm{NaCl}$ secretion; epithelial proliferation; and role in colitis

Mediates dendritic cells maturation and migration; granulocytic differentiation

Platelet aggregation; dense granule secretion

Regulates lipid metabolism and atherosclerosis

Hematopoietic stem cells chemotaxis; dendritic cell activation

Platelet activation; smooth muscle contraction

Sensory transmission and modulation of synaptic function

Mediates sensory transmission; facilitates glutamate release in CNS

Modulates chronic inflammatory and neuropathic pain

Mediating cell proliferation and differentiation

Functions as a heteromeric channel in combination with P2X2 and P2X4 subunits

Mediates apoptosis, cell proliferation and pro-inflammatory cytokine release

Modulates neurotransmitter release; treatment in cardiac tachycardia

Anti-inflammatory effect; mediates cytokines release; facilitates

neurotransmission; and smooth muscle relaxation

Dampens inflammation in allergic and inflammatory disorders; vasodilatation

Mediates anti-inflammatory, anti-ischemic, and antitumor effect 
stabilin $2(47,48)$, and members of the $\mathrm{T}$ cell immunoglobulin mucin domain (TIM) protein family (including TIM1, TIM3, and TIM4) (49-51). The recognition of apoptotic cells can also be mediated indirectly via bridging molecules or accessory receptors, such as MFG-E8, the C-reactive protein, and Gas-6 (52, 53). Engagement of the PS receptors initiates signaling events within the phagocytes that lead to activation of the small GTPase Rac, and subsequent cytoskeletal reorganization, which ultimately leads to engulfment of the apoptotic cell $(54,55)$.

The engulfment process is not only silent, but also actively anti-inflammatory. Firstly, phagocytes act as "garbage collectors," which sequester dying cells thus preventing the release of potentially dangerous or immunogenic intracellular contents. Secondly, engulfed phagocytes actively secrete anti-inflammatory cytokines to facilitate the "immunologically silent" clearance of apoptotic cells. These include TGF- $\beta$ and interleukin (IL)-10, which is even potent enough to suppress LPS-induced inflammatory cytokine release $(10,56,57)$. A recent report demonstrates that 12/15lipoxygenase has been involved in maintaining immunologic tolerance (58). The uptake of apoptotic cells by 12/15-lipoxygenase expressing, alternatively activated resident macrophages blocked the uptake of apoptotic cells into freshly recruited inflammatory Ly $6^{\mathrm{Chi}}$ monocytes. Moreover, loss of 12/15-lipoxygenase activity resulted in an aberrant phagocytosis of apoptotic cells by inflammatory monocytes, subsequent antigen presentation of apoptotic cell-derived antigens, and a lupus-like autoimmune disease (58).

If apoptotic cells are not removed promptly they will undergo secondary necrosis and display distinctive morphological changes that can be assessed by flow cytometry $(59,60)$. Insufficient clearance of dying cells may promote the initiation of autoimmunity and chronic inflammation $(61,62)$. For example, deregulated apoptosis and insufficient removal of apoptotic cells leads to the release of modified chromatin into the circulation and activation of antigen-presenting cells, which play an important role in the pathogenesis of systemic lupus erythematosus $(61,63)$. Interestingly, recent studies imply that apoptosis is associated with compensatory proliferation of neighboring cells and plays a pivotal role in modulating tumor cell repopulation $(64,65)$. For example, Huang et al. reported that dying tumor cells produce PGE2 in a caspase 3-dependent manner and that this has a potent growth-stimulating effect that may stimulate tumor repopulation after radiotherapy (66). The role of further "find me" signals and damage-associated molecular pattern molecules (DAMPs) released by tumor cells killed by chemo- or radiotherapy in the repopulation of the tumor remains elusive. Here, we present a current review that nucleotides derived from dead and dying cells as powerful mediators with broad effects on survival of tumor cells and on the immune system.

\section{NUCLEOTIDES ACTING AS "FIND ME" SIGNALS}

It is well established that apoptotic cells release "find me" signals to attract phagocytes and thereby leading to the prompt clearance of the dying cells. The nucleotides ATP and UTP have been recently implicated as a new class of "find me" signals in vitro and in vivo (39). However, the function of ATP and nucleotides as a find me signal in apoptotic cell clearance is still controversial.
Elliot et al.'s study shows that small amounts of intracellular ATP and UTP are released in a regulated manner during early apoptosis to establish a gradient for monocyte attraction (39). Pannexin 1 channels opening mediate the release of ATP and UTP after caspase-dependent cleavage of their carboxy-terminal tail during apoptosis (67). Several other studies also seem to confirm that nucleotides released from apoptotic cells and subsequent P2Y2 receptor activation promotes monocyte migration by regulating adhesion molecule/chemokine expression in vascular endothelial cells $(68,69)$. In the neural system, extracellular nucleotides and P2YRs have been implicated in mediating the chemotaxis of microglia toward injured neurons $(70,71)$.

However, the role of nucleotides in chemotaxis still remains controversial. On the one hand, Elliot et al. could not exclude the possibility that other chemotactic factors participate in the observed chemoattractant effect. On the other hand, nucleotides are unlikely to serve as long-range "find me" signals to phagocytes since they are readily degraded by extracellular nucleotidases (72). Several recent publications do not consider ATP any longer as a "real" direct chemoattractant for macrophages. One study describes ATP as an indirect chemoattractant that steers macrophages in a gradient of the chemoattractant C5a via autocrine release of ATP, generating an amplification of gradient sensing via a "purinergic feedback loop" involving P2Y2 and P2Y12 receptors (73). Hanley et al. confirmed that ATP and ADP leaking from dying cells induce lamellipodial membrane protrusive activity and act as local short-range "touch me" (rather than long-range "find me") signals to promote phagocytic clearance (74). It is more likely that ATP, together with additional find me signals recruit phagocytes toward injured cells $(75,76)$. For example, formyl peptides and mitochondrial DNA released from the mitochondria of injured cells have been shown to induce neutrophil activation and chemotaxis in the circulation (77). Formyl peptides, together with chemokines and ATP, synergistically guide and localize phagocytes to sites of sterile inflammation in long-range settings (75). HMGB1 could also synergize with ATP stimulating P2X7 receptors to induce IL- $1 \beta$ release by DCs in contact with dying tumor cells and promoting immunity against tumors (78).

Moreover, nucleotides also play a role in modulating the phagocytic ability or activity of cells surrounding the apoptotic cells. For example, extracellular nucleotides and subsequent P2 receptor (P2X1R, P2X3R) signaling engagement have been reported to enhance the ability of macrophages to bind apoptotic bodies, internalize them and present processed antigens (79). UDP has also been shown to enhance microglia phagocytosis toward apoptotic corpses through the P2Y6 nucleotide receptor during neural inflammation (80).

During tissue injury and/or infection, extracellular nucleotides have been implicated to play a key role in the recruitment of professional phagocytes to sites of tissue injury and/or infection. However, the underlying mechanism is still unclear and not fully understood. It is still debating that extracellular nucleotides act either as chemotactic "find me" signal released by dying cells or through autocrine ATP amplifier signaling for chemotactic navigation to other end-target chemoattractants, such as complement C5a. 


\section{P2 RECEPTORS SIGNALING IN INFLAMMATORY DISEASES}

Nucleotides release from dying cells and damaged tissues and subsequent purinergic signaling play a pivotal role in phagocytic process and inflammatory diseases $(11,12)$. For example, P2X7R activation is involved in PS expose in pseudoapoptosis and large amounts of ATP release $(81,82)$. During the last decade, several studies have highlighted fundamental roles for P2YRs in inflammatory and infectious diseases (Figure 1). Here in particular, signaling events via P2Y2R, P2Y6R, and P2X7R will be discussed thoroughly.

\section{P2Y2R}

P2Y2R has been shown to be up-regulated in a variety of tissues in response to stress or injury and to mediate tissue regeneration through its ability to activate multiple signaling pathways. Many studies implicate that ATP and P2Y2R signaling appears to influence a diverse scale of biological processes such as the generation of chemotactic signals and/or the activation of different immune cells, causing inflammatory cells to migrate, proliferate, differentiate, or release diverse inflammatory mediators $(72,83,84)$.

Cystic fibrosis is a life-shortening disease in which airways of the patients are susceptible to infection. Its pathology is characterized by protective and also destructive neutrophilic inflammation. Neutrophil proteases are critical for killing engulfed bacteria, however, neutrophilic elastase accumulation in the airways of patients with cystic fibrosis (CF) overwhelms antiprotease defenses, resulting in impaired ciliary function, crippling bacterial clearance, and degrading structural proteins, eventually leading to bronchiectasis (85). CF results from a variety of mutations in the gene encoding the CF transmembrane conductance regulator (CFTR) protein, a cAMP-regulated chloride channel in epithelial cells, which will lead to sodium hyperabsorption in the airway of patients with
CF $(86,87)$. Mucociliary clearance in CF lung is limited by airway dehydration, leading to persistent bacterial infection and inflammation. P2Y2 receptors have been shown to regulate chloride secretion and sodium absorption on epithelial cells in distal bronchi (88). Moreover, ATP, acting through P2Y2 receptors, regulates the secretion of ions, mucin, and surfactant phospholipids in respiratory epithelium (89). Several studies have shown that P2 receptor purinergic compounds are explored for the treatment of $\mathrm{CF}$, to bypass the defective function of CFTR, and to restore chloride secretion and/or inhibit sodium absorption through inhibiting the epithelial sodium channel $\mathrm{ENaC}$ expression (90). P2Y2R agonists increase the duration of mucociliary clearance stimulation. The efficacy and safety of the P2Y2R agonist denufosol has been evaluated in several clinical trials, however, long term follow-up results do not show any improvement in pulmonary function $(91,92)$.

$\mathrm{P} 2 \mathrm{Y} 2 \mathrm{R}$ is not only involved in enhancing mucociliary clearance, but also plays a role in promoting wound healing (93). Damaged fibroblasts release ATP or UTP and activate P2Y2R to enhance the proliferation and migration of fibroblasts. Wound size in WT mice decreases significantly compared to $\mathrm{P} 2 \mathrm{Y}_{2} \mathrm{R}^{-1-}$ mice, and WT mice express proliferation marker Ki67 and extracellular matrix (ECM)-related proteins VEGF. It indicates that triggering of P2Y2R may be a potential therapeutic target to promote wound healing (94).

Adenosine $5^{\prime}$-triphosphate has also been implicated to induce chemotaxis of neutrophils via actin polymerization and direct cell orientation by feedback signaling involving P2Y2R (95-97). The subsequent P2Y2R activation will amplify gradient sensing of chemotactic signals (e.g., $\mathrm{N}$-formyl peptides and IL-8) by stimulating F-actin to the leading edge (97-99). Chemotaxis of neutrophils to sites of infection is critical for immune defense

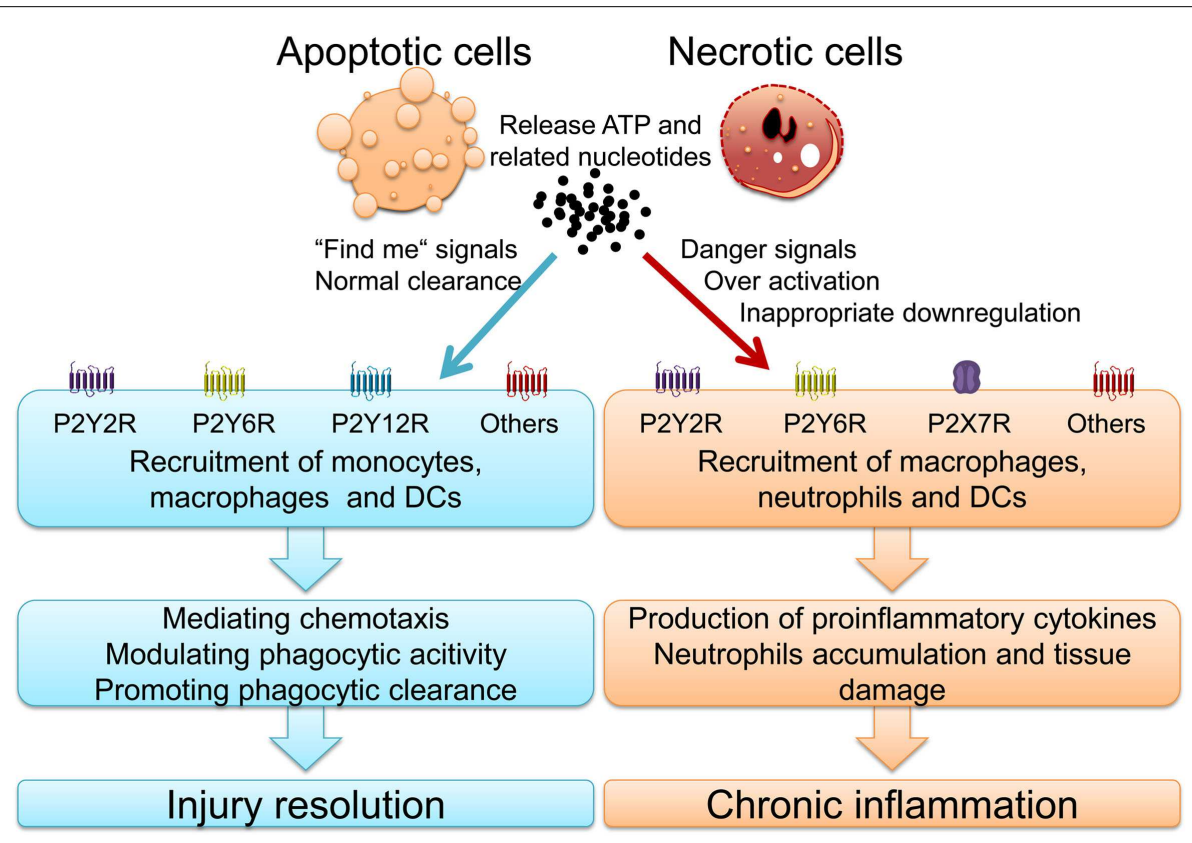

FIGURE 1 | Nucleotides and activated purinergic signaling during injury resolution and chronic inflammatory diseases 
and for the physiological downregulation of neutrophil-driven inflammation (100).

However, excessive accumulation of neutrophils through inappropriate activation of $\mathrm{P} 2 \mathrm{Y} 2 \mathrm{R}$ can cause acute tissue damage during sepsis, chronic obstructive pulmonary disease (COPD), and hepatitis (101-104). COPD is one of the most common inflammatory diseases and is associated with inflammation of the small airways, which results in airway obstruction, destruction of parenchyma, and development of emphysema (105). ATP and activation of $\mathrm{P} 2 \mathrm{Y} 2 \mathrm{R}$ contribute to smoke-induced lung inflammation and to the subsequent development of emphysema (104). ATP acts as a "danger signal" recruiting neutrophils to the lung and inducing inflammation. $\mathrm{P} 2 \mathrm{Y} 2 \mathrm{R}^{-1-}$ mice show reduced pulmonary inflammation and less emphysema development after short-term smoke exposure. ATP enhances chemotaxis and elastase release in blood neutrophils from patients with COPD, compared to normal healthy subjects (103).

In asthmatic chronic airway inflammation, P2Y2R has been indicated as a critical sensor for airway exposure to airborne allergens by mediating ATP-triggered migration of immature monocyte-derived DCs and eosinophils in both, mice and humans $(106,107)$. This process is accompanied with the production of pro-allergic mediators (for example, IL-33, IL-8, eosinophil cationic protein) from different cellular sources $(107,108)$. Moreover, heightened expression and localization patterns of P2YR are associated with chronic pancreatic diseases (109).

In summary, ATP and P2Y2R signaling is a double-edged sword. On the one hand, it can protect against infections, promote wound healing and enhance mucociliary clearance. On the other hand, it can also lead to uncontrolled inflammation and promotion of chronic inflammatory disease states and fibrotic remodeling (Figure 1) (109). Indeed, P2Y2R may be a new target for therapy of COPD and P2Y2R antagonists could be useful drugs for chronic inflammatory diseases.

\section{P2Y6R}

Similar to P2Y2R, P2Y6R plays an ambivalent role in inflammatory diseases. The receptor is crucial for innate immune responses against bacterial infection (110). Many studies show that P2Y6R activation is involved in the release of chemokines from immune cells, such as monocytes, DCs, eosinophils, and recruiting monocytes/macrophages during inflammation or infection (24, 110-114).

In neurodegenerative diseases, microglia are engaged in the clearance of dead cells or dangerous debris, which is crucial for the maintenance of brain functions. Extracellular ATP regulates microglial motility dynamics in the intact brain, and its release from the damaged tissues mediates a rapid microglial response toward injury (71). Moreover, UTP and UDP released from injured neurons have been shown to enhance microglial phagocytic capacity for dying cells via activation of P2Y6R, serving as an "eat-me" signal for microglia. This signal is considered to be an important initiator of the clearance of dying cells or debris in the CNS (80).

However, P2Y6R signaling is relatively harmful in endothelial or epithelial inflammation $(111,115)$. The idiopathic inflammatory bowel diseases (IBD) comprise two types of chronic intestinal disorders: Crohn's disease and ulcerative colitis, which result from an inappropriate inflammatory response to intestinal microbes in a genetically susceptible host (116). Up-regulation of P2Y2R and P2Y6R in intestinal epithelial cells has been reported in experimental colitis (115).

Similarly, P2Y6R plays an important role in acute and chronic allergic airway inflammation, and selective blocking of P2Y6R or P2Y6R deficiency in structural cells reduces symptoms of experimental asthma. Recently, P2Y6 receptors have not only been found to be up-regulated in murine atherosclerotic plaques, but also to play a key role in MSU-associated inflammatory diseases $(117,118)$.

Thus, P2Y6R activation plays a role in innate immunity against infection whereas P2Y6R over-activation can result in harmful immune responses and chronic inflammation such as atherosclerosis, COPD, and IBD (Figure 1).

\section{P2X7R}

P2X7R are predominantly expressed on immune cells such as mast cells, macrophages, microglia, and dendritic cells (119). Many evidences implicate the role of P2X7R against microbes during inflammation and immune response $(120,121)$. Indeed, P2X7R signaling plays a key role in immune responses against bacterial and parasitic infection. It has been reported that P2X7R signaling is involved in the elimination of intracellular microbes - such as Mycobacterium tuberculosis, Chlamydia trachomatis, and Leishmania amazonensis - either by contributing to killing of the pathogen or by inducing cell death of infected macrophages (121). P2X7R is also involved in fever development via PGE2 and IL-1 $\beta$ production (122).

The $\mathrm{P} 2 \mathrm{X} 7 \mathrm{R}$ is widely recognized to mediate the proinflammatory effects of extracellular ATP. However, recently one study revealed that $\mathrm{P} 2 \mathrm{X} 7$ receptor also acts as one of the scavenger receptor involved in the recognition and removal of apoptotic cells in the absence of extracellular ATP and serum (123). The P2X7R has drawn particular attention as a potential drug target due to its broad involvement in inflammatory diseases (124).

In the CNS, P2X7R activation contributes to neuroinflammation through the release of pro-inflammatory cytokines, such as IL- $1 \beta$ and TNF- $\alpha(125,126)$. It also activates MAP kinases and $\mathrm{NF}-\kappa \mathrm{B}$, resulting in up-regulation of pro-inflammatory gene products, including COX-2 (127) and the P2Y2R (128). Alzheimer's disease $(\mathrm{AD})$ is the most common form of dementia and more than 35 million people worldwide suffer from AD (129). The appearance of plaques consisting of extracellular $\beta$-amyloid peptide $(\mathrm{A} \beta)$ is a neuro-pathological feature of $\mathrm{AD}$, which is surrounded by reactive microglial cells $(129,130)$. In $\mathrm{P} 2 \mathrm{X} \mathrm{R}^{-/-}$mice, $\mathrm{A} \beta$ triggered increase of intracellular $\mathrm{Ca}^{2+}$, ATP release, IL- $1 \beta$ secretion, and plasma membrane permeabilization in microglia (131). In fact, in vivo inhibition of P2X7R in mice transgenic for mutant human amyloid precursor protein (APP) indicated a significant decrease of the number of hippocampal amyloid plaques (132). Thus, the identification of extracellular ATP and P2X7R as key factors in $A \beta$-dependent microglia activation unveils a nonconventional mechanism in neuroinflammation and suggests new possible pharmacological targets.

Extracellular ATP and P2X7R signaling also contributes to the development of smoking-induced lung inflammation and emphysema. $\mathrm{P} 2 \mathrm{X} 7 \mathrm{R}^{-1-}$ mice exhibit decreased inflammatory responses, including a reduction in pulmonary fibrosis in a mouse 
model of lung inflammation (133). Inhibition of this receptor may be a new possible therapeutic target for the treatment of COPD $(133,134)$.

The purinergic P2X7R is associated with activation and release of IL-1 and IL-18, which is strongly implicated in the multiple inflammatory pathways involved in the pathogenesis of rheumatoid arthritis (RA) (135-139). P2X7R has also been shown to be expressed by synoviocytes from RA joints and contributes to modulation of IL-6 release (140). P2X7R activation also plays a novel and direct role in tissue damage through release of cathepsins in joint diseases (141). Although, AZD9056, a P2X7R antagonist, has been shown to reduce articular inflammation and erosive progression (142), clinical trials with the P2X7R antagonist in patients with RA failed to inhibit disease progression $(143,144)$. Similarly, the effect and safety of AZD9056 in Crohn's disease is still under clinical trial (145).

Taken together, P2X7R signaling not only plays a critical role in mediating appropriate inflammatory and immunological responses against invading pathogens, but also contributes to a wide range of chronic inflammatory diseases when activated inappropriately (Figure 1).

\section{CONCLUSION}

The interaction between dying cells and phagocytes is very complex and nucleotides have been involved in orchestrating the process of dead cell removal. On the one hand, nucleotides and purinergic signaling have been shown to play a key role in the apoptotic cell clearance avoiding secondary necrosis, preventing inflammation and contributing to regeneration of injured tissues. On the other hand, purinergic signaling over-activation is involved in chronic inflammation and chronic inflammatory diseases. Adenosine-mediated P1 and nucleotides-mediated P2 signaling frequently have opposing effects in biological systems, and shifting the balance between P1 and P2 signaling is an important therapeutic concept in efforts to dampen pathological inflammation and promote healing (12). Nucleotides and purinergic signaling might be used as biomarkers for various diseases and could also provide potential novel therapeutic targets for the treatment of chronic inflammatory diseases.

\section{ACKNOWLEDGMENTS}

The present work was supported by the National Science Foundation of China (81273286) to Dr. Yi Zhao.

\section{REFERENCES}

1. Thompson CB. Apoptosis in the pathogenesis and treatment of disease. Science (1995) 267(5203):1456-62. doi:10.1126/science.7878464

2. Delbridge AR, Valente LJ, Strasser A. The role of the apoptotic machinery in tumor suppression. Cold Spring Harb Perspect Biol (2012) 4(11):1-14. doi:10.1101/cshperspect.a008789

3. Bjorkerud S, Bjorkerud B. Apoptosis is abundant in human atherosclerotic lesions, especially in inflammatory cells (macrophages and T cells), and may contribute to the accumulation of gruel and plaque instability. Am J Pathol (1996) 149(2):367-80.

4. Rossi ML, Marziliano N, Merlini PA, Bramucci E, Canosi U, Belli G, et al. Different quantitative apoptotic traits in coronary atherosclerotic plaques from patients with stable angina pectoris and acute coronary syndromes. Circulation (2004) 110(13):1767-73. doi:10.1161/01.CIR.0000142865.04816.89
5. Tanaka M, Miyake Y. Apoptotic cell clearance and autoimmune disorder. Curr Med Chem (2007) 14(27):2892-7. doi:10.2174/092986707782360006

6. Munoz LE, Lauber K, Schiller M, Manfredi AA, Herrmann M. The role of defective clearance of apoptotic cells in systemic autoimmunity. Nat Rev Rheumatol (2010) 6(5):280-9. doi:10.1038/nrrheum.2010.46

7. Ravichandran KS. Find-me and eat-me signals in apoptotic cell clearance: progress and conundrums. J Exp Med (2010) 207(9):1807-17. doi:10.1084/ jem.20101157

8. Nagata S, Hanayama R, Kawane K. Autoimmunity and the clearance of dead cells. Cell (2010) 140(5):619-30. doi:10.1016/j.cell.2010.02.014

9. Peter C, Wesselborg S, Herrmann M, Lauber K. Dangerous attraction: phagocyte recruitment and danger signals of apoptotic and necrotic cells. Apoptosis (2010) 15(9):1007-28. doi:10.1007/s10495-010-0472-1

10. Voll RE, Herrmann M, Roth EA, Stach C, Kalden JR, Girkontaite I. Immunosuppressive effects of apoptotic cells. Nature (1997) 390(6658):350-1. doi:10. $1038 / 37022$

11. Bours MJL, Swennen ELR, Di Virgilio F, Cronstein BN, Dagnelie PC. Adenosine 5'-triphosphate and adenosine as endogenous signaling molecules in immunity and inflammation. Pharmacol Ther (2006) 112(2):358-404. doi:10.1016/ j.pharmthera.2005.04.013

12. Eltzschig HK, Sitkovsky MV, Robson SC. Purinergic signaling during inflammation. N Engl J Med (2012) 367(24):2322-33. doi:10.1056/NEJMra1205750

13. Di Virgilio F. Purinergic mechanism in the immune system: a signal of danger for dendritic cells. Purinergic Signal (2005) 1(3):205-9. doi:10.1007/s11302005-6312-z

14. Schroder K, Tschopp J. The inflammasomes. Cell (2010) 140(6):821-32. doi:10.1016/j.cell.2010.01.040

15. Burnstock G. Purinergic signalling and disorders of the central nervous system. Nat Rev Drug Discov (2008) 7(7):575-90. doi:10.1038/nrd2605

16. Praetorius HA, Leipziger J. ATP release from non-excitable cells. Purinergic Signal (2009) 5(4):433-46. doi:10.1007/s11302-009-9146-2

17. Yegutkin GG. Nucleotide- and nucleoside-converting ectoenzymes: important modulators of purinergic signalling cascade. Biochim Biophys Acta (2008) 1783(5):673-94. doi:10.1016/j.bbamcr.2008.01.024

18. Zimmermann H. Extracellular metabolism of ATP and other nucleotides. Naunyn Schmiedebergs Arch Pharmacol (2000) 362(4-5):299-309. doi:10.1007/ s002100000309

19. Gray JH, Owen RP, Giacomini KM. The concentrative nucleoside transporter family, SLC28. Pflugers Arch (2004) 447(5):728-34. doi:10.1007/s00424-0031107-y

20. Baldwin SA, Beal PR, Yao SYM, King AE, Cass CE, Young JD. The equilibrative nucleoside transporter family, SLC29. Pflugers Arch (2004) 447(5):735-43. doi:10.1007/s00424-003-1103-2

21. Ralevic V, Burnstock G. Receptors for purines and pyrimidines. Pharmacol Rev (1998) 50(3):413-92.

22. Jacobson KA, Balasubramanian R, Deflorian F, Gao ZG. G protein-coupled adenosine (P1) and $\mathrm{P} 2 \mathrm{Y}$ receptors: ligand design and receptor interactions. Purinergic Signal (2012) 8(3):419-36. doi:10.1007/s11302-012-9294-7

23. Jarvis MF, Khakh BS. ATP-gated P2X cation-channels. Neuropharmacology (2009) 56(1):208-15. doi:10.1016/j.neuropharm.2008.06.067

24. Abbracchio MP, Burnstock G, Boeynaems JM, Barnard EA, Boyer JL, Kennedy $\mathrm{C}$, et al. International union of pharmacology LVIII: update on the P2Y G protein-coupled nucleotide receptors: from molecular mechanisms and pathophysiology to therapy. Pharmacol Rev (2006) 58(3):281-341. doi:10.1124/pr. 58.3.3

25. Compan V, Ulmann L, Stelmashenko O, Chemin J, Chaumont S, Rassendren F. P2X2 and P2X5 subunits define a new heteromeric receptor with P2X7-like properties. J Neurosci (2012) 32(12):4284-96. doi:10.1523/JNEUROSCI.633211.2012

26. Fredholm BB, Ijzerman AP, Jacobson KA, Linden J, Muller CE. International union of basic and clinical pharmacology. LXXXI. Nomenclature and classification of adenosine receptors - an update. Pharmacol Rev (2011) 63(1):1-34. doi:10.1124/pr.110.003285

27. Hasko G, Linden J, Cronstein B, Pacher P. Adenosine receptors: therapeutic aspects for inflammatory and immune diseases. Nat Rev Drug Discov (2008) 7(9):759-70. doi:10.1038/nrd2638

28. Eltzschig HK. Adenosine: an old drug newly discovered. Anesthesiology (2009) 111(4):904-15. doi:10.1097/ALN.0b013e3181b060f2 
29. Burnstock G. Purine and pyrimidine receptors. Cell Mol Life Sci (2007) 64(12):1471-83. doi:10.1007/s00018-007-6497-0

30. Burnstock G. Introduction: ATP and its metabolites as potent extracellular agonists. In: Schwiebert EM, editor. Current Topics in Membranes, Volume 54, Purinergic Receptors and Signalling. San Diego: Academic Press (2003). p. 1-7.

31. Abbracchio MP, Burnstock G, Verkhratsky A, Zimmermann H. Purinergic signalling in the nervous system: an overview. Trends Neurosci (2009) 32(1):19-29. doi:10.1016/j.tins.2008.10.001

32. Goffinet M, Tardy C, Boubekeur N, Cholez G, Bluteau A, Oniciu DC, et al. $\mathrm{P} 2 \mathrm{Y} 13$ receptor regulates HDL metabolism and atherosclerosis in vivo. PLoS One (2014) 9(4):e95807. doi:10.1371/journal.pone.0095807

33. Wang N, Robaye B, Gossiel F, Boeynaems JM, Gartland A. The P2Y13 receptor regulates phosphate metabolism and FGF-23 secretion with effects on skeletal development. FASEB J (2014) 28(5):2249-59. doi:10.1096/fj.13-243626

34. Henson PM. Dampening inflammation. Nat Immunol (2005) 6(12):1179-81. doi:10.1038/ni1205-1179

35. Hochreiter-Hufford A, Ravichandran KS. Clearing the dead: apoptotic cell sensing, recognition, engulfment, and digestion. Cold Spring Harb Perspect Biol (2013) 5(1):a008748. doi:10.1101/cshperspect.a008748

36. Ravichandran KS, Lorenz U. Engulfment of apoptotic cells: signals for a good meal. Nat Rev Immunol (2007) 7(12):964-74. doi:10.1038/nri2214

37. Biermann M, Maueroder C, Brauner JM, Chaurio R, Janko C, Herrmann M, et al. Surface code - biophysical signals for apoptotic cell clearance. Phys Biol (2013) 10(6):065007. doi:10.1088/1478-3975/10/6/065007

38. Biermann MH, Veissi S, Maueroder C, Chaurio R, Berens C, Herrmann $\mathrm{M}$, et al. The role of dead cell clearance in the etiology and pathogenesis of systemic lupus erythematosus: dendritic cells as potential targets. Expert Rev Clin Immunol (2014) 10(9):1151-64. doi:10.1586/1744666X.2014. 944162

39. Elliott MR, Chekeni FB, Trampont PC, Lazarowski ER, Kadl A, Walk SF, et al. Nucleotides released by apoptotic cells act as a find-me signal to promote phagocytic clearance. Nature (2009) 461(7261):282-6. doi:10.1038/ nature 08296

40. Lauber K, Bohn E, Krober SM, Xiao YJ, Blumenthal SG, Lindemann RK, et al. Apoptotic cells induce migration of phagocytes via caspase-3-mediated release of a lipid attraction signal. Cell (2003) 113(6):717-30. doi:10.1016/S00928674(03)00422-7

41. Truman LA, Ford CA, Pasikowska M, Pound JD, Wilkinson SJ, Dumitriu IE, et al. CX3CL1/fractalkine is released from apoptotic lymphocytes to stimulate macrophage chemotaxis. Blood (2008) 112(13):5026-36. doi:10.1182/blood2008-06-162404

42. Gude DR, Alvarez SE, Paugh SW, Mitra P, Yu J, Griffiths R, et al. Apoptosis induces expression of sphingosine kinase 1 to release sphingosine-1phosphate as a "come-and-get-me" signal. FASEB J (2008) 22(8):2629-38. doi:10.1096/fj.08-107169

43. Bournazou I, Pound JD, Duffin R, Bournazos S, Melville LA, Brown SB, et al. Apoptotic human cells inhibit migration of granulocytes via release of lactoferrin. J Clin Invest (2009) 119(1):20-32. doi:10.1172/JCI36226

44. Fadok VA, Voelker DR, Campbell PA, Cohen JJ, Bratton DL, Henson PM. Exposure of phosphatidylserine on the surface of apoptotic lymphocytes triggers specific recognition and removal by macrophages. J Immunol (1992) 148(7):2207-16.

45. Martin SJ, Reutelingsperger CP, McGahon AJ, Rader JA, van Schie RC, LaFace $\mathrm{DM}$, et al. Early redistribution of plasma membrane phosphatidylserine is a general feature of apoptosis regardless of the initiating stimulus: inhibition by overexpression of Bcl-2 and Abl. J Exp Med (1995) 182(5):1545-56. doi:10.1084/jem.182.5.1545

46. Park D, Tosello-Trampont AC, Elliott MR, Lu M, Haney LB, Ma Z, et al. BAIl is an engulfment receptor for apoptotic cells upstream of the ELMO/Dock180/Rac module. Nature (2007) 450(7168):430-4. doi:10.1038/ nature06329

47. Park SY, Jung MY, Kim HJ, Lee SJ, Kim SY, Lee BH, et al. Rapid cell corpse clearance by stabilin-2, a membrane phosphatidylserine receptor. Cell Death Differ (2008) 15(1):192-201. doi:10.1038/sj.cdd.4402242

48. Park SY, Kim SY, Jung MY, Bae DJ, Kim IS. Epidermal growth factor-like domain repeat of stabilin-2 recognizes phosphatidylserine during cell corpse clearance. Mol Cell Biol (2008) 28(17):5288-98. doi:10.1128/MCB.01993-07

49. Kobayashi N, Karisola P, Pena-Cruz V, Dorfman DM, Jinushi M, Umetsu SE, et al. TIM-1 and TIM-4 glycoproteins bind phosphatidylserine and mediate uptake of apoptotic cells. Immunity (2007) 27(6):927-40. doi:10.1016/j. immuni.2007.11.011

50. Miyanishi M, Tada K, Koike M, Uchiyama Y, Kitamura T, Nagata S. Identification of Tim4 as a phosphatidylserine receptor. Nature (2007) 450(7168):435-9. doi:10.1038/nature06307

51. Nakayama M, Akiba H, Takeda K, Kojima Y, Hashiguchi M, Azuma M, et al. Tim-3 mediates phagocytosis of apoptotic cells and cross-presentation. Blood (2009) 113(16):3821-30. doi:10.1182/blood-2008-10-185884

52. Gregory CD, Pound JD. Cell death in the neighbourhood: direct microenvironmental effects of apoptosis in normal and neoplastic tissues. J Pathol (2011) 223(2):177-94. doi:10.1002/path.2792

53. Kruse K, Janko C, Urbonaviciute V, Mierke CT, Winkler TH, Voll RE, et al. Inefficient clearance of dying cells in patients with SLE: anti-dsDNA autoantibodies, MFG-E8, HMGB-1 and other players. Apoptosis (2010) 15(9):1098-113. doi:10.1007/s10495-010-0478-8

54. Gumienny TL, Brugnera E, Tosello-Trampont AC, Kinchen JM, Haney LB, Nishiwaki K, et al. CED-12/ELMO, a novel member of the CrkII/Dock180/Rac pathway, is required for phagocytosis and cell migration. Cell (2001) 107(1):27-41. doi:10.1016/S0092-8674(01)00520-7

55. Albert ML, Kim JI, Birge RB. Alphavbeta5 integrin recruits the CrkIIDock180-rac1 complex for phagocytosis of apoptotic cells. Nat Cell Biol (2000) 2(12):899-905. doi:10.1038/35046549

56. Fadok VA, Bratton DL, Konowal A, Freed PW, Westcott JY, Henson PM. Macrophages that have ingested apoptotic cells in vitro inhibit proinflammatory cytokine production through autocrine/paracrine mechanisms involving TGF-beta, PGE2, and PAF. J Clin Invest (1998) 101(4):890-8. doi:10.1172/ JCI1112

57. Huynh ML, Fadok VA, Henson PM. Phosphatidylserine-dependent ingestion of apoptotic cells promotes TGF-betal secretion and the resolution of inflammation. J Clin Invest (2002) 109(1):41-50. doi:10.1172/JCI200211638

58. Uderhardt S, Herrmann M, Oskolkova OV, Aschermann S, Bicker W, Ipseiz N, et al. 12/15-lipoxygenase orchestrates the clearance of apoptotic cells and maintains immunologic tolerance. Immunity (2012) 36(5):834-46. doi:10.1016/j. immuni.2012.03.010

59. Munoz LE, Maueroder C, Chaurio R, Berens C, Herrmann M, Janko C. Colourful death: six-parameter classification of cell death by flow cytometry - dead cells tell tales. Autoimmunity (2013) 46(5):336-41. doi:10.3109/ 08916934.2012.755960

60. Janko C, Munoz L, Chaurio R, Maueroder C, Berens C, Lauber K, et al. Navigation to the graveyard-induction of various pathways of necrosis and their classification by flow cytometry. Methods Mol Biol (2013) 1004:3-15. doi:10.1007/978-1-62703-383-1_1

61. Herrmann M, Voll RE, Zoller OM, Hagenhofer M, Ponner BB, Kalden JR. Impaired phagocytosis of apoptotic cell material by monocyte-derived macrophages from patients with systemic lupus erythematosus. Arthritis Rheum (1998) 41(7):1241-50. doi:10.1002/1529-0131(199807)41:7<1241: :AID-ART15>3.0.CO;2-H

62. Munoz LE, Janko C, Grossmayer GE, Frey B, Voll RE, Kern P, et al. Remnants of secondarily necrotic cells fuel inflammation in systemic lupus erythematosus. Arthritis Rheum (2009) 60(6):1733-42. doi:10.1002/art.24535

63. Gaipl US, Munoz LE, Grossmayer G, Lauber K, Franz S, Sarter K, et al. Clearance deficiency and systemic lupus erythematosus (SLE). J Autoimmun (2007) 28(2-3):114-21. doi:10.1016/j.jaut.2007.02.005

64. Lauber K, Munoz LE, Berens C, Jendrossek V, Belka C, Herrmann M. Apoptosis induction and tumor cell repopulation: the yin and yang of radiotherapy. Radiat Oncol (2011) 6:176. doi:10.1186/1748-717X-6-176

65. Yamaguchi H, Maruyama T, Urade Y, Nagata S. Immunosuppression via adenosine receptor activation by adenosine monophosphate released from apoptotic cells. Elife (2014) 3:e02172. doi:10.7554/eLife.02172

66. Huang Q, Li F, Liu X, Li W, Shi W, Liu FF, et al. Caspase 3-mediated stimulation of tumor cell repopulation during cancer radiotherapy. Nat Med (2011) 17(7):860-6. doi:10.1038/nm.2385

67. Chekeni FB, Elliott MR, Sandilos JK, Walk SF, Kinchen JM, Lazarowski $\mathrm{ER}$, et al. Pannexin 1 channels mediate 'find-me' signal release and membrane permeability during apoptosis. Nature (2010) 467(7317):863-U136. doi:10.1038/nature09413

68. Goepfert C, Sundberg C, Sevigny J, Enjyoji K, Hoshi T, Csizmadia E, et al. Disordered cellular migration and angiogenesis in cd39-null mice. Circulation (2001) 104(25):3109-15. doi:10.1161/hc5001.100663 
69. Seye CI, Yu N, Jain R, Kong Q, Minor T, Newton J, et al. The P2Y2 nucleotide receptor mediates UTP-induced vascular cell adhesion molecule-1 expression in coronary artery endothelial cells. J Biol Chem (2003) 278(27):24960-5. doi:10.1074/jbc.M301439200

70. Honda S, Sasaki Y, Ohsawa K, Imai Y, Nakamura Y, Inoue K, et al. Extracellular ATP or ADP induce chemotaxis of cultured microglia through $\mathrm{G}(\mathrm{i} / \mathrm{o})$-coupled P2Y receptors. J Neurosci (2001) 21(6):1975-82.

71. Davalos D, Grutzendler J, Yang G, Kim JV, Zuo Y, Jung S, et al. ATP mediates rapid microglial response to local brain injury in vivo. Nat Neurosci (2005) 8(6):752-8. doi:10.1038/nn1472

72. Di Virgilio F, Chiozzi P, Ferrari D, Falzoni S, Sanz JM, Morelli A, et al. Nucleotide receptors: an emerging family of regulatory molecules in blood cells. Blood (2001) 97(3):587-600. doi:10.1182/blood.V97.3.587

73. Kronlage M, Song JA, Sorokin L, Isfort K, Schwerdtle T, Leipziger J, et al. Autocrine purinergic receptor signaling is essential for macrophage chemotaxis. Sci Signal (2010) 3(132):ra55. doi:10.1126/scisignal.2000588

74. Isfort K, Ebert F, Bornhorst J, Sargin S, Kardakaris R, Pasparakis M, et al. Realtime imaging reveals that $\mathrm{P} 2 \mathrm{Y} 2$ and $\mathrm{P} 2 \mathrm{Y} 12$ receptor agonists are not chemoattractants and macrophage chemotaxis to complement C5a is phosphatidylinositol 3-kinase (PI3K)- and p38 mitogen-activated protein kinase (MAPK)independent. J Biol Chem (2011) 286(52):44776-87. doi:10.1074/jbc.M111. 289793

75. McDonald B, Pittman K, Menezes GB, Hirota SA, Slaba I, Waterhouse CC, et al. Intravascular danger signals guide neutrophils to sites of sterile inflammation. Science (2010) 330(6002):362-6. doi:10.1126/science.1195491

76. Peter C, Wesselborg S, Lauber K. Molecular suicide notes: last call from apoptosing cells. J Mol Cell Biol (2010) 2(2):78-80. doi:10.1093/jmcb/mjp045

77. Zhang Q, Raoof M, Chen Y, Sumi Y, Sursal T, Junger W, et al. Circulating mitochondrial DAMPs cause inflammatory responses to injury. Nature (2010) 464(7285):104-U115. doi:10.1038/nature08780

78. Ghiringhelli F, Apetoh L, Tesniere A, Aymeric L, Ma YT, Ortiz C, et al. Activation of the NLRP3 inflammasome in dendritic cells induces IL-1 beta-dependent adaptive immunity against tumors. Nat Med (2009) 15(10):1170-U99. doi:10. 1038/nm.2028

79. Marques-da-Silva C, Burnstock G, Ojcius DM, Coutinho-Silva R. Purinergic receptor agonists modulate phagocytosis and clearance of apoptotic cells in macrophages. Immunobiology (2011) 216(1-2):1-11. doi:10.1016/j.imbio. 2010.03.010

80. Koizumi S, Shigemoto-Mogami Y, Nasu-Tada K, Shinozaki Y, Ohsawa K, Tsuda $\mathrm{M}$, et al. UDP acting at P2Y6 receptors is a mediator of microglial phagocytosis. Nature (2007) 446(7139):1091-5. doi:10.1038/nature05704

81. Pellegatti P, Falzoni S, Pinton P, Rizzuto R, Di Virgilio F. A novel recombinant plasma membrane-targeted luciferase reveals a new pathway for ATP secretion. Mol Biol Cell (2005) 16(8):3659-65. doi:10.1091/mbc.E05-03-0222

82. Mackenzie AB, Young MT, Adinolfi E, Surprenant A. Pseudoapoptosis induced by brief activation of ATP-gated P2X7 receptors. J Biol Chem (2005) 280(40):33968-76. doi:10.1074/jbc.M502705200

83. Ferrari D, la Sala A, Panther E, Norgauer J, Di Virgilio F, Idzko M. Activation of human eosinophils via P2 receptors: novel findings and future perspectives. J Leukoc Biol (2006) 79(1):7-15. doi:10.1189/jlb.0505286

84. Jacob F, Perez Novo C, Bachert C, Van Crombruggen K. Purinergic signaling in inflammatory cells: P2 receptor expression, functional effects, and modulation of inflammatory responses. Purinergic Signal (2013) 9(3):285-306. doi:10.1007/s11302-013-9357-4

85. Davis SD, Ferkol T. Identifying the origins of cystic fibrosis lung disease. N Engl J Med (2013) 368(21):2026-8. doi:10.1056/NEJMe1303487

86. Welsh MJ, Smith AE. Molecular mechanisms of CFTR chloride channel dysfunction in cystic-fibrosis. Cell (1993) 73(7):1251-4. doi:10.1016/00928674(93)90353-R

87. Ismailov II, Awayda MS, Jovov B, Berdiev BK, Fuller CM, Dedman JR, et al. Regulation of epithelial sodium channels by the cystic fibrosis transmembrane conductance regulator. J Biol Chem (1996) 271(9):4725-32. doi:10.1074/jbc. 271.9.4725

88. Inglis SK, Collett A, McAlroy HL, Wilson SM, Olver RE. Effect of luminal nucleotides on $\mathrm{Cl}$ - secretion and $\mathrm{Na}+$ absorption in distal bronchi. Pflugers Arch (1999) 438(5):621-7. doi:10.1007/s004240051085

89. Kishore BK, Ginns SM, Krane CM, Nielsen S, Knepper MA. Cellular localization of $\mathrm{P} 2 \mathrm{Y}(2)$ purinoceptor in rat renal inner medulla and lung. Am J Physiol Renal Physiol (2000) 278(1):F43-51.
90. Burnstock G, Brouns I, Adriaensen D, Timmermans JP. Purinergic signaling in the airways. Pharmacol Rev (2012) 64(4):834-68. doi:10.1124/pr.111.005389

91. Deterding RR, LaVange LM, Engels JM, Mathews DW, Coquillette SJ, Brody AS, et al. Phase 2 randomized safety and efficacy trial of nebulized denufosol tetrasodium in cystic fibrosis. Am J Respir Crit Care Med (2007) 176(4):362-9. doi:10.1164/rccm.200608-12380C

92. Ratjen F, Durham T, Navratil T, Schaberg A, Accurso FJ, Wainwright C, et al. Long term effects of denufosol tetrasodium in patients with cystic fibrosis. J Cyst Fibros (2012) 11(6):539-49. doi:10.1016/j.jcf.2012.05.003

93. Gendaszewska-Darmach E, Kucharska M. Nucleotide receptors as targets in the pharmacological enhancement of dermal wound healing. Purinergic Signal (2011) 7(2):193-206. doi:10.1007/s11302-011-9233-z

94. Jin H, Seo J, Eun SY, Joo YN, Park SW, Lee JH, et al. P2Y2 R activation by nucleotides promotes skin wound-healing process. Exp Dermatol (2014) 23(7):480-5. doi:10.1111/exd.12440

95. Verghese MW, Kneisler TB, Boucheron JA. P2U agonists induce chemotaxis and actin polymerization in human neutrophils and differentiated HL60 cells. J Biol Chem (1996) 271(26):15597-601. doi:10.1074/jbc.271.26.15597

96. Junger WG. Purinergic regulation of neutrophil chemotaxis. Cell Mol Life Sci (2008) 65(16):2528-40. doi:10.1007/s00018-008-8095-1

97. Chen Y, Corriden R, Inoue Y, Yip L, Hashiguchi N, Zinkernagel A, et al. ATP release guides neutrophil chemotaxis via P2Y2 and A3 receptors. Science (2006) 314(5806):1792-5. doi:10.1126/science.1132559

98. Chen Y, Yao YL, Sumi Y, Li A, To UK, Elkhal A, et al. Purinergic signaling: a fundamental mechanism in neutrophil activation. Sci Signal (2010) 3(125):ra45. doi:10.1126/scisignal.2000549

99. Kukulski F, Ben Yebdri F, Lecka J, Kauffenstein G, Levesque SA, Martin-Satue $\mathrm{M}$, et al. Extracellular ATP and P2 receptors are required for IL-8 to induce neutrophil migration. Cytokine (2009) 46(2):166-70. doi:10.1016/j.cyto.2009. 02.011

100. Schauer C, Janko C, Munoz LE, Zhao Y, Kienhofer D, Frey B, et al. Aggregated neutrophil extracellular traps limit inflammation by degrading cytokines and chemokines. Nat Med (2014) 20(5):511-7. doi:10.1038/nm.3547

101. Inoue Y, Chen Y, Hirsh MI, Yip L, Junger WG. A3 and P2Y2 receptors control the recruitment of neutrophils to the lungs in a mouse model of sepsis. Shock (2008) 30(2):173-7. doi:10.1097/shk.0b013e318160dad4

102. Ayata CK, Ganal SC, Hockenjos B, Willim K, Vieira RP, Grimm M, et al. Purinergic $\mathrm{P} 2 \mathrm{Y}(2)$ receptors promote neutrophil infiltration and hepatocyte death in mice with acute liver injury. Gastroenterology (2012) 143(6):1620-1629e4. doi:10.1053/j.gastro.2012.08.049

103. Lommatzsch M, Cicko S, Muller T, Lucattelli M, Bratke K, Stoll P, et al. Extracellular adenosine triphosphate and chronic obstructive pulmonary disease. Am J Respir Crit Care Med (2010) 181(9):928-34. doi:10.1164/rccm.200910$1506 \mathrm{OC}$

104. Cicko S, Lucattelli M, Muller T, Lommatzsch M, De Cunto G, Cardini S, et al. Purinergic receptor inhibition prevents the development of smokeinduced lung injury and emphysema. J Immunol (2010) 185(1):688-97. doi:10.4049/jimmunol.0904042

105. Hogg JC, Chu F, Utokaparch S, Woods R, Elliott WM, Buzatu L, et al. The nature of small-airway obstruction in chronic obstructive pulmonary disease. N Engl J Med (2004) 350(26):2645-53. doi:10.1056/NEJMoa032158

106. Idzko M, Hammad H, van Nimwegen M, Kool M, Willart MAM, Muskens F, et al. Extracellular ATP triggers and maintains asthmatic airway inflammation by activating dendritic cells. Nat Med (2007) 13(8):913-9. doi:10.1038/nm1617

107. Muller T, Vieira RD, Grimm M, Cicko S, Idzko M. The purinergic receptor P2Y2 mediates chemotaxis of dendritic cells and eosinophils in allergic lung inflammation. Allergy (2010) 65:26-7. doi:10.1111/j.1398-9995.2010.02426.x

108. Kouzaki H, Iijima K, Kobayashi T, O’Grady SM, Kita H. The danger signal, extracellular ATP, is a sensor for an airborne allergen and triggers IL33 release and innate Th2-type responses. J Immunol (2011) 186(7):4375-87. doi:10.4049/jimmunol.1003020

109. Kunzli BM, Berberat PO, Giese T, Csizmadia E, Kaczmarek E, Baker C, et al. Upregulation of CD39/NTPDases and P2 receptors in human pancreatic disease. Am J Physiol Gastrointest Liver Physiol (2007) 292(1):G223-30. doi:10.1152/ajpgi.00259.2006

110. Zhang Z, Wang Z, Ren H, Yue M, Huang K, Gu H, et al. P2Y(6) agonist uridine 5 '-diphosphate promotes host defense against bacterial infection via monocyte chemoattractant protein-1-mediated monocytes/macrophages recruitment. J Immunol (2011) 186(9):5376-87. doi:10.4049/jimmunol.1002946 
111. Riegel AK, Faigle M, Zug S, Rosenberger P, Robaye B, Boeynaems JM, et al. Selective induction of endothelial P2Y6 nucleotide receptor promotes vascular inflammation. Blood (2011) 117(8):2548-55. doi:10.1182/blood-2010-10313957

112. Vieira RP, Muller T, Grimm M, von Gernler V, Vetter B, Durk T, et al. Purinergic receptor type 6 contributes to airway inflammation and remodeling in experimental allergic airway inflammation. Am J Respir Crit Care Med (2011) 184(2):215-23. doi:10.1164/rccm.201011-1762OC

113. Idzko M, Panther E, Sorichter S, Herouy Y, Berod L, Geissler M, et al. Characterization of the biological activities of uridine diphosphate in human dendritic cells: influence on chemotaxis and CXCL8 release. J Cell Physiol (2004) 201(2):286-93. doi:10.1002/jcp.20070

114. Ferrari D, Idzko M, Dichmann S, Purlis D, Virchow C, Norgauer J, et al. P2 purinergic receptors of human eosinophils: characterization and coupling to oxygen radical production. FEBS Lett (2000) 486(3):217-24. doi:10.1016/ S0014-5793(00)02306-1

115. Grbic D, Degagne E, Langlois C, Dupuis AA, Gendron FP. Intestinal inflammation increases P2Y6 receptor expression on epithelial cells and the release of CXCL8 by UDP. Purinergic Signal (2008) 4:S184-184. doi:10.4049/jimmunol. 180.4.2659

116. Abraham C, Cho JH. Inflammatory bowel disease. N Engl J Med (2009) 361(21):2066-78. doi:10.1056/NEJMra0804647

117. Guns PJDF, Hendrickx J, Van Assche T, Fransen P, Bult H. P2Y receptors and atherosclerosis in apolipoprotein E-deficient mice. Br J Pharmacol (2010) 159(2):326-36. doi:10.1111/j.1476-5381.2009.00497.x

118. Uratsuji H, Tada Y, Kawashima T, Kamata M, Hau CS, Asano Y, et al. P2Y6 receptor signaling pathway mediates inflammatory responses induced by monosodium urate crystals. J Immunol (2012) 188(1):436-44. doi:10.4049/ jimmunol.1003746

119. Junger WG. Immune cell regulation by autocrine purinergic signalling. Nat Rev Immunol (2011) 11(3):201-12. doi:10.1038/nri2938

120. North RA, Jarvis MF. P2X receptors as drug targets. Mol Pharmacol (2013) 83(4):759-69. doi:10.1124/mol.112.083758

121. Coutinho-Silva R, Ojcius DM. Role of extracellular nucleotides in the immune response against intracellular bacteria and protozoan parasites. Microbes Infect (2012) 14(14):1271-7. doi:10.1016/j.micinf.2012.05.009

122. Barbera-Cremades M, Baroja-Mazo A, Gomez AI, Machado F, Di Virgilio F, Pelegrin P. P2X7 receptor-stimulation causes fever via PGE2 and IL-1 beta release. FASEB J (2012) 26(7):2951-62. doi:10.1096/fj.12-205765

123. Wiley JS, Gu BJ. A new role for the P2X7 receptor: a scavenger receptor for bacteria and apoptotic cells in the absence of serum and extracellular ATP. Purinergic Signal (2012) 8(3):579-86. doi:10.1007/s11302-012-9308-5

124. Sperlagh B, Illes P. P2X7 receptor: an emerging target in central nervous system diseases. Trends Pharmacol Sci (2014) 35(10):537-47. doi:10.1016/j.tips.2014. 08.002

125. Tschopp J, Schroder K. NLRP3 inflammasome activation: the convergence of multiple signalling pathways on ROS production? Nat Rev Immunol (2010) 10(3):210-5. doi:10.1038/nri2725

126. Lister MF, Sharkey J, Sawatzky DA, Hodgkiss JP, Davidson DJ, Rossi AG, et al. The role of the purinergic P2X7 receptor in inflammation. J Inflamm (Lond) (2007) 4:5. doi:10.1186/1476-9255-4-5

127. Skaper SD, Debetto P, Giusti P. The P2X7 purinergic receptor: from physiology to neurological disorders. FASEB J (2010) 24(2):337-45. doi:10.1096/fj. $09-138883$

128. Degagne E, Grbic DM, Dupuis AA, Lavoie EG, Langlois C, Jain N, et al. P2Y2 receptor transcription is increased by NF-kappa B and stimulates cyclooxygenase-2 expression and PGE2 released by intestinal epithelial cells. J Immunol (2009) 183(7):4521-9. doi:10.4049/jimmunol.0803977

129. Querfurth HW, LaFerla FM. Alzheimer's disease. N Engl J Med (2010) 362(4):329-44. doi:10.1056/NEJMra0909142

130. Delarasse C, Auger R, Gonnord P, Fontaine B, Kanellopoulos JM. The purinergic receptor $\mathrm{P} 2 \mathrm{X} 7$ triggers alpha-secretase-dependent processing of the amyloid precursor protein. J Biol Chem (2011) 286(4):2596-606. doi:10.1074/jbc. M110.200618

131. Sanz JM, Chiozzi P, Ferrari D, Colaianna M, Idzko M, Falzoni S, et al. Activation of microglia by amyloid \{beta\} requires P2X7 receptor expression. J Immunol (2009) 182(7):4378-85. doi:10.4049/jimmunol.0803612
132. Diaz-Hernandez JI, Gomez-Villafuertes R, Leon-Otegui M, Hontecillas-Prieto L, Del Puerto A, Trejo JL, et al. In vivo P2X7 inhibition reduces amyloid plaques in Alzheimer's disease through GSK3beta and secretases. Neurobiol Aging (2012) 33(8):1816-28. doi:10.1016/j.neurobiolaging.2011.09.040

133. Lucattelli M, Cicko S, Muller T, Lommatzsch M, De Cunto G, Cardini S, et al. P2X7 receptor signaling in the pathogenesis of smoke-induced lung inflammation and emphysema. Am J Respir Cell Mol Biol (2011) 44(3):423-9. doi:10.1165/rcmb.2010-0038OC

134. Eltom S, Stevenson CS, Rastrick J, Dale N, Raemdonck K, Wong S, et al. $\mathrm{P} 2 \mathrm{X} 7$ receptor and caspase 1 activation are central to airway inflammation observed after exposure to tobacco smoke. PLoS One (2011) 6(9):e24097. doi:10.1371/journal.pone.0024097

135. Ferrari D, Pizzirani C, Adinolfi E, Lemoli RM, Curti A, Idzko M, et al. The P2X7 receptor: a key player in IL-1 processing and release. J Immunol (2006) 176(7):3877-83. doi:10.4049/jimmunol.176.7.3877

136. Surprenant A, Rassendren F, Kawashima E, North RA, Buell G. The cytolytic $\mathrm{P} 2 \mathrm{Z}$ receptor for extracellular ATP identified as a $\mathrm{P} 2 \mathrm{X}$ receptor $(\mathrm{P} 2 \mathrm{X} 7)$. Science (1996) 272(5262):735-8. doi:10.1126/science.272.5262.735

137. Sluyter R, Dalitz JG, Wiley JS. P2X7 receptor polymorphism impairs extracellular adenosine 5'-triphosphate-induced interleukin-18 release from human monocytes. Genes Immun (2004) 5(7):588-91. doi:10.1038/sj.gene.6364127

138. Kay J, Calabrese L. The role of interleukin-1 in the pathogenesis of rheumatoid arthritis. Rheumatology (2004) 43:2-9. doi:10.1093/rheumatology/keh201

139. Shao XT, Feng L, Gu LJ, Wu LJ, Feng TT, Yang YM, et al. Expression of interleukin-18, IL-18BP, and IL-18R in serum, synovial fluid, and synovial tissue in patients with rheumatoid arthritis. Clin Exp Med (2009) 9(3):215-21. doi:10.1007/s10238-009-0036-2

140. Caporali F, Capecchi PL, Gamberucci A, Lazzerini PE, Pompella G, Natale $\mathrm{M}$, et al. Human rheumatoid synoviocytes express functional P2X7 receptors. J Mol Med (Berl) (2008) 86(8):937-49. doi:10.1007/s00109-008-0365-8

141. Lopez-Castejon G, Theaker J, Pelegrin P, Clifton AD, Braddock M, Surprenant A. P2X(7) Receptor-mediated release of cathepsins from macrophages is a cytokine-independent mechanism potentially involved in joint diseases. J Immunol (2010) 185(4):2611-9. doi:10.4049/jimmunol.1000436

142. McInnes IB, Cruwys S, Bowers K, Braddock M. Targeting the P2X7 receptor in rheumatoid arthritis: biological rationale for P2X7 antagonism. Clin Exp Rheumatol (2014).

143. Stock TC, Bloom BJ, Wei N, Ishaq S, Park W, Wang X, et al. Efficacy and safety of CE-224,535, an antagonist of P2X7 receptor, in treatment of patients with rheumatoid arthritis inadequately controlled by methotrexate. J Rheumatol (2012) 39(4):720-7. doi:10.3899/jrheum.110874

144. Keystone EC, Wang MM, Layton M, Hollis S, McInnes IB. Clinical evaluation of the efficacy of the P2X7 purinergic receptor antagonist AZD9056 on the signs and symptoms of rheumatoid arthritis in patients with active disease despite treatment with methotrexate or sulphasalazine. Ann Rheum Dis (2012) 71(10):1630-5. doi:10.1136/annrheumdis-2011-143578

145. Ochoa-Cortes F, Linan-Rico A, Jacobson KA, Christofi FL. Potential for developing purinergic drugs for gastrointestinal diseases. Inflamm Bowel Dis (2014) 20(7):1259-87. doi:10.1097/MIB.0000000000000047

Conflict of Interest Statement: The authors declare that the research was conducted in the absence of any commercial or financial relationships that could be construed as a potential conflict of interest.

Received: 09 November 2014; accepted: 08 December 2014; published online: 23 December 2014.

Citation: Chen J, Zhao Y and Liu Y (2014) The role of nucleotides and purinergic signaling in apoptotic cell clearance - implications for chronic inflammatory diseases. Front. Immunol. 5:656. doi: 10.3389/fimmu.2014.00656

This article was submitted to Inflammation, a section of the journal Frontiers in Immunology.

Copyright (c) 2014 Chen, Zhao and Liu. This is an open-access article distributed under the terms of the Creative Commons Attribution License (CC BY). The use, distribution or reproduction in other forums is permitted, provided the original author (s) or licensor are credited and that the original publication in this journal is cited, in accordance with accepted academic practice. No use, distribution or reproduction is permitted which does not comply with these terms. 